\title{
Enhanced Gold Biosorption of Lysinibacillus sphaericus CBAM5 by Encapsulation of Bacteria in an Alginate Matrix
}

\author{
Carolina Páez-Vélez ${ }^{1}$, Ricardo E. Rivas ${ }^{2}$ and Jenny Dussán ${ }^{1, *(1)}$ \\ 1 Microbiological Research Center (CIMIC), Department of Biological Sciences, Universidad de Los Andes, \\ Bogotá 111711, Colombia \\ 2 Department of Chemistry, Universidad de Los Andes, Bogotá 111711, Colombia \\ * Correspondence: jdussan@uniandes.edu.co; Tel.: +57-1-339-4949
}

Received: 23 May 2019; Accepted: 24 June 2019; Published: 25 July 2019

check for updates

\begin{abstract}
Given its variety of properties, including conductivity and slow corrosion, the industrial uses for gold are increasing dramatically. This means that greater amounts of gold are being released into the environment and that a biological approach to recycling gold is of great interest. Lysinibacillus sphaericus, a bacterium capable of metal accumulation inside the cell and adsorption in the external surface, was encapsulated in an alginate matrix to improve the capture of gold from aqueous media. In this study, L. sphaericus CBAM5 proved to have the greatest potential compared to other strains and, following its encapsulation, the efficiency for the removal of the precious metal, at a concentration of $60 \mathrm{ppm}$, was $100 \%$ after three hours of exposure. It was identified that the alginate spheres with bacteria could also be reused. In fact, an efficiency of $60 \%$ was retained after three cycles of utilization. Thus, alginate acts as an adequate immobilization matrix for bacteria as a highly effective gold capture mechanism, which also shows great potential as an alternative for biotechnological applications.
\end{abstract}

Keywords: gold; biosorption; encapsulation; alginate; Lysinibacillus sphaericus

\section{Introduction}

The use of gold for the development of new technologies based on gold nanoparticles in the pharmaceutical, electronic, and electrical industries is on the increase [1]. This means that significant quantities of this precious metal are being released into the environment through industrial waste water and mining activities [1,2]. Some conventional technologies are used to capture metals from wastewaters-for example, precipitation, chemical oxidation or reduction, reverse osmosis, coagulation, and electrochemical treatment, among others [3]. Nevertheless, these methods are expensive and are incapable of achieving high efficiencies [3]. Thus, the ability to recycle gold from different residual samples is of great interest and, in this respect, sorption by microorganisms is an expanding area of research $[4,5]$.

Previous studies demonstrate that certain types of bacteria possess heavy metal resistance and detoxification mechanisms, which may be extracellular or intracellular and specific to a certain metal or to a variety of them [6]. This type of bacteria can therefore proliferate in metal-contaminated environments and may be able to capture these metals [7,8]. As an example, Lysinibacillus sphaericus is a gram-positive bacterium isolated from a uranium mining waste pile [9], which has a surface layer (S-layer) protein, a porous lattice that protects it and acts as an ion trap. Moreover, several studies have revealed $L$. sphaericus' ability to accumulate heavy metals such as $\mathrm{Pb}(\mathrm{II}), \mathrm{Cr}(\mathrm{VI}), \mathrm{Cd}(\mathrm{II})$, among others [10-13] due to its S-layer protein and heavy metal efflux pumps [11,14]. It has also recently been 
found that L. sphaericus is able to accumulate and adsorb $\mathrm{Au}(\mathrm{III})$ and that there is evidence for the biosynthesis of gold nanoparticles or colloids [1,15].

Given the protection it provides against environmental stress, the immobilization of bacterial cells could improve their tolerance and capacity to remove contaminants [16]. Several matrices like chitosan, chitin, cellulose, alginate or polyvinyl alcohol are known to protect against UV radiation, toxins, desiccation, contaminants from the medium and possible competing microorganisms [17]. For example, alginate is an algal polysaccharide commonly used in the food industry [18] and it has been demonstrated that it may provide an efficient means to encapsulate bacteria to capture heavy metals such as $\mathrm{Cr}(\mathrm{VI})$ [12]. This type of matrix gives not only protection to the cell $[12,13]$ but it also provides a controlled environment for bacterial cells [18] due to its porosity that allows the dissolved contaminants to pass through it, increasing the retention time in the matrix. Other advantages related to the immobilization of bacteria are the increase of biosorption rates as a result of a higher cell density, and the easy separation of the biomass in the solid phase from the liquid media [19].

Based on the above, an alginate matrix was used to encapsulate L. sphaericus cells in order to improve their gold biosorption performance while protecting them to reuse the encapsulated biomass for several cycles. A comparative study between free and encapsulated L. sphaericus cells was performed and the gold biosorption efficiency was evaluated.

\section{Materials and Methods}

\subsection{Strains of L. sphaericus and Growth Conditions}

The strains used in these experiments were selected based on information from previous studies that showed their potential to capture heavy metals from aqueous media $[11,12,15,20]$. Each of the selected L. sphaericus strains shown in Table 1 were incubated in nutrient broth (OXOID) for $15 \mathrm{~h}$ at $30^{\circ} \mathrm{C}$ and $150 \mathrm{rpm}$. They were then harvested by centrifugation $\left(11,000 \mathrm{rpm}, 15 \mathrm{~min}\right.$ and $\left.4{ }^{\circ} \mathrm{C}\right)$ and resuspended in minimum salt medium (MSM). This medium contains: $\mathrm{KH}_{2} \mathrm{PO}_{4} 0.5 \mathrm{~g} / \mathrm{L}, \mathrm{NH}_{4} \mathrm{Cl} 1 \mathrm{~g} / \mathrm{L}$, $\mathrm{Na}_{2} \mathrm{SO}_{4} 2 \mathrm{~g} / \mathrm{L}, \mathrm{KNO}_{3} 2 \mathrm{~g} / \mathrm{L}, \mathrm{CaCl}_{2} 0.001 \mathrm{~g} / \mathrm{L}, \mathrm{FeSO}_{4} 0.0004 \mathrm{~g} / \mathrm{L}, \mathrm{MgSO}_{4} \cdot 7 \mathrm{H}_{2} \mathrm{O} 1 \mathrm{~g} / \mathrm{L}$, sodium acetate 5 $\mathrm{g} / \mathrm{L}$. The resuspended bacteria had an optical density $\left(\mathrm{OD}_{605} \mathrm{~nm}\right)$ of $0.9-1.2$ and were then used for the gold biosorption assays.

Table 1. Strains of L. sphaericus evaluated in the biosorption assays.

\begin{tabular}{ccc}
\hline L. sphaericus Strains & Site of Isolation & Reference \\
\hline CBAM5 & Hydrocarbon-contaminated soil & {$[14]$} \\
III(3)7 & Oak forest soil & {$[14]$} \\
OT4b.31 & Coleopteran larvae & {$[14]$} \\
MCB1 & Nechi River & {$[15]$} \\
MCB2 & Nechi River & {$[15]$} \\
\hline
\end{tabular}

\subsection{Biosorption of Gold by Free-Living L. sphaericus Cells}

Each of the five L. sphaericus strains (Table 1) were grown and the biosorption assay was conducted as previously described [15]. Briefly, the assay was undertaken in $50 \mathrm{~mL}$ flasks with MSM to a final volume of $15 \mathrm{~mL}, \mathrm{HAuCl}_{4} \cdot 3 \mathrm{H}_{2} \mathrm{O}(60 \mathrm{mg} / \mathrm{L})$ and $3 \mathrm{~mL}$ of each strain suspension. For the assay with the mixture of strains, $1 \mathrm{~mL}$ of each bacteria suspension (L. sphaericus CBAM5, III(3)7 and MCB2) was used. The assays were incubated at $30^{\circ} \mathrm{C}, 130 \mathrm{rpm}$. A control assay was made using the same conditions as above but without adding cells for the inoculation. The experiment was conducted in triplicate. Following this, aliquots of $1.5 \mathrm{~mL}$ were taken at times $0,0.25,0.5,1,1.5$ and $2 \mathrm{~h}$ and centrifuged at $13,000 \mathrm{rpm}$ and $4{ }^{\circ} \mathrm{C}$. The supernatants were analyzed by flame atomic absorption spectroscopy (FAAS), described later. 


\subsection{L. sphaericus CBAM5 Immobilization in an Alginate Matrix}

Due to its high efficiency for gold removal, L. sphaericus CBAM5 was the strain selected for the immobilization assays. A total of $0.6 \mathrm{~g}$ of sodium alginate was poured and homogenized in $60 \mathrm{~mL}$ of a L. sphaericus CBAM5 suspension in MSM and in $60 \mathrm{~mL}$ of MSM (negative control). These solutions were added separately dropwise to a $\mathrm{CaCl}_{2}$ sterilized solution (2\%) in distilled water. The resulting spheres were separated and washed with sterile distilled water. Using $0.5 \mathrm{~g}$ of spheres, the bacteria concentration was determined by crushing and mixing them with $1 \mathrm{~mL}$ of sterile saline solution (0.85\%). Standard serial 10-fold dilutions were inoculated $(10 \mu \mathrm{L})$ in nutrient agar and incubated for $20 \mathrm{~h}$ at 30 ${ }^{\circ} \mathrm{C}$ for the drop plate count method [21].

\subsection{Biosorption of Gold by Encapsulated Cells of L. sphaericus CBAM5 in Alginate}

For this assay, $10 \mathrm{~g}$ of alginate spheres with L. sphaericus CBAM5 and no cells (negative control) were added to $\mathrm{MSM}$ and $\mathrm{HAuCl}_{4} \cdot 3 \mathrm{H}_{2} \mathrm{O}(60 \mathrm{mg} / \mathrm{L})$ to obtain a final volume of $15 \mathrm{~mL}$ in $50 \mathrm{~mL}$ flasks. The mixture was incubated at $30^{\circ} \mathrm{C}$ and $150 \mathrm{rpm}$. Aliquots of $1.5 \mathrm{~mL}$ were taken from the flasks at times $0,15,30 \mathrm{~min}$ and 1, 1.5 and 2, 3 and $4 \mathrm{~h}$ and centrifuged at 13,000 rpm and $4{ }^{\circ} \mathrm{C}$. FAAS was used to analyze the gold concentration in the supernatants as described below. The bioassay was conducted in triplicate. To identify the stability of L. sphaericus CBAM5 in the alginate matrix, the bacteria concentration after $24 \mathrm{~h}$ was determined as described above. This was also performed for the negative control spheres to confirm their sterility.

\subsection{Reusability Test}

To determine the potential reusability of the alginate spheres with encapsulated bacteria, gold biosorption assays were performed three times. Prior to each cycle, the spheres were washed with distilled water and exposed to gold as described above. Aliquots of $1.5 \mathrm{~mL}$ were taken from the flasks at times 0 and $4 \mathrm{~h}$. Gold concentration in the supernatant was measured by FAAS and gold capture efficiency was calculated. The washing steps were performed after each cycle and all assays were conducted in triplicate.

\subsection{Release of Bacteria from Alginate Spheres}

The protocol for quantification of the bacteria released was described before [18]. Minor modifications were made as follows: $1 \mathrm{~g}$ of alginate spheres with encapsulated bacteria were suspended in $10 \mathrm{~mL}$ of sterile saline solution $(0.85 \% \mathrm{w} / \mathrm{v})$ in $15 \mathrm{~mL}$ flasks and incubated at $30^{\circ} \mathrm{C}$ and $150 \mathrm{rpm}$. At times 0 and $72 \mathrm{~h}, 1 \mathrm{~mL}$ aliquots were collected and standard serial 10-fold dilutions were inoculated $(10 \mu \mathrm{L})$ in nutrient agar for the drop plate count method after $20 \mathrm{~h}$ of incubation at $30{ }^{\circ} \mathrm{C}$.

\subsection{Flame Atomic Absorption Spectrometry (FAAS) Measurements}

All the experiments for the quantification of gold were carried out using a high-resolution continuum source atomic absorption spectrometer (HR-CSAAS, ContrAa 800, commercially available from Analytik Jena, Jena, Germany) in flame mode (FAAS). Flame conditions were properly optimized before the measurements, using the absorption line at $242.7590 \mathrm{~nm}$. All gold standards were made on the measurement day by diluting $1000 \mathrm{mg} / \mathrm{L}$ standard $\left(\mathrm{HAuCl}_{4}, \mathrm{CertiPUR}\right.$, Merck, $\left.\mathrm{HCl} 2 \mathrm{~mole} / \mathrm{L}\right)$ to concentrations between 2 and 10 ppm. Distilled water and hydrochloric acid 1 mole/L (ACS reagent, $37 \%$, Merck) were used to acidify and dilute all standards and samples at 5\% (M/V).

\subsection{Scanning Electron Microscopy (SEM) and Energy Dispersive X-ray Spectroscopy (EDS) Analysis}

The remaining spheres were observed using scanning electron microscopy (SEM). Spheres from the assays were collected and sequentially washed with ethanol at 70\%, 90\% and 100\%. They were then frozen using liquid nitrogen and cut in half. An aluminum support was used for metallization and SEM observation of the samples. In addition, a semi-quantification of the metal with energy dispersive 
X-ray spectroscopy (EDS) was performed using the equipment JEOL JSM-6490LV (JEOL, Tokyo, Japan) scanning electron microscope equipped with an Oxford INCA PentaFetX3 EDS detector.

\subsection{Statistical Analysis}

Data obtained from the bioassays were analyzed using one-way ANOVA followed by the Tukey test at $\mathrm{P}<0.05$. All the analyses were performed using Software RStudio (R 3.5.1) (Boston, MA, USA).

\section{Results}

\subsection{Biosorption of Gold by Free-Living Cells of L. sphaericus}

In order to identify the efficiency of gold capture by free cells of five strains of L. sphaericus, the metal concentration in the supernatants was followed by using FAAS during a period of $2 \mathrm{~h}$ because previous studies showed that gold adsorption occurs in a brief period of time (Figure 1). In terms of single strains, L. sphaericus CBAM5 showed the best efficiency with a decrease of $52 \%$ of $\mathrm{Au}(\mathrm{III})$ in the supernatant, followed by MCB2 and III(3)7, although non-significant differences were determined for these two strains. As those three strains (CBAM5, MCB2 and III(3)7) presented the highest efficiency, they were chosen to assess gold capture by a mixture of cells. After $2 \mathrm{~h}$, a decrease of $33 \%$ of Au(III) was observed, showing that single L. sphaericus CBAM5 is more efficient for gold sorption. The control assay showed that the concentration of gold remained stable during the two hours of the experiment, which validates the results for the free cells.

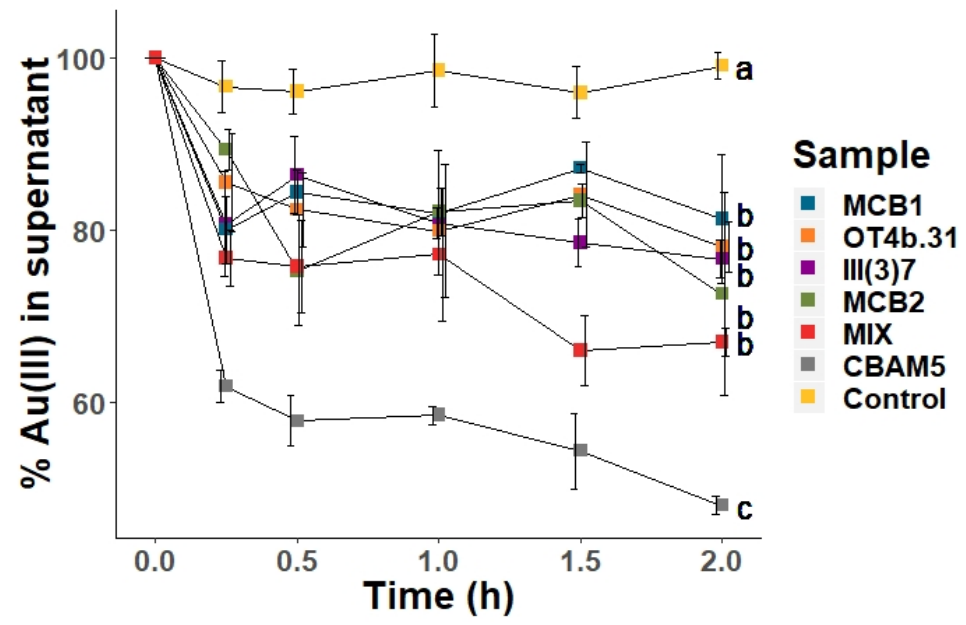

Figure 1. Gold (60 ppm) biosorption assay with free cells of L. sphaericus strains and a mixture (MIX) of some of them (CBAM5, MCB2 and III(3)7) with an $\mathrm{OD}_{605}=0.9-1.2, \mathrm{pH}=5-6$, for $2 \mathrm{~h}$. Points at 2 $\mathrm{h}$ denoted by a different letter differ significantly at $\mathrm{P}<0.05$ according to a one-way ANOVA and a Tukey analysis.

\subsection{Biosorption of Gold by Encapsulated Cells of L. sphaericus CBAM5 in Alginate}

As L. sphaericus CBAM5 was the most efficient strain in the assay with free cells, it was chosen for encapsulation in an alginate matrix. Its capacity to capture gold was examined by using FAAS within the first two hours of the experiment (Figure 2). A rapid decrease of the gold percentage in the supernatant was observed, and after two hours, $97 \%$ of $\mathrm{Au}(\mathrm{III})$ was captured by the cells in the alginate spheres, indicating an improvement when encapsulating the bacteria. The control assay showed that the spheres without cells can capture $60 \%$ of gold after $1.5 \mathrm{~h}$ and a desorption process occurs after two hours of the experiment and only $10 \%$ of gold is retained in the alginate matrix. 


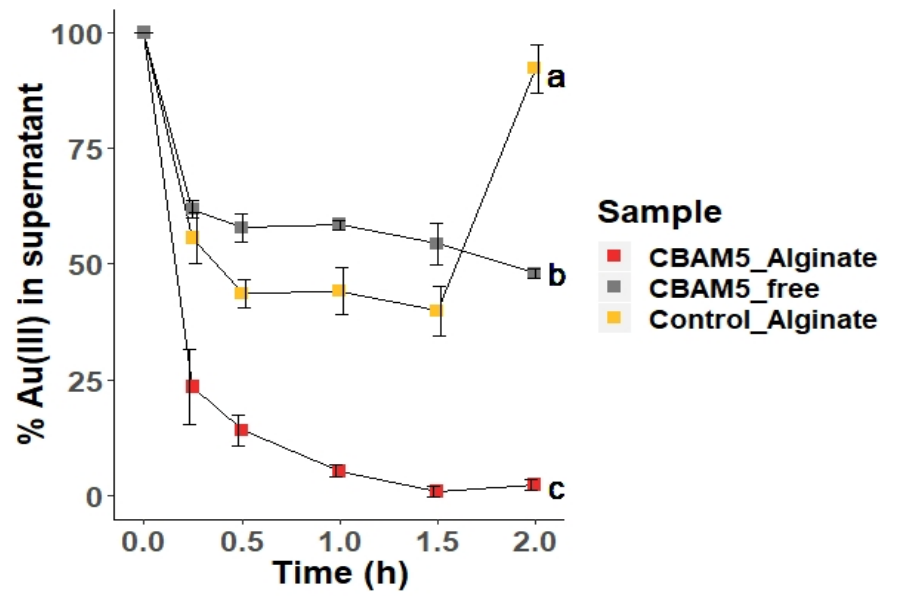

Figure 2. Gold (60 ppm) biosorption assays with free (CBAM5_free) and encapsulated (CBAM5_Alginate) cells of L. sphaericus CBAM5 with $\mathrm{pH}=5-6$. Control_Alginate: assay with alginate spheres without bacteria. Points at $2 \mathrm{~h}$ denoted by a different letter differ significantly at $\mathrm{P}<$ 0.05 according to a one-way ANOVA and a Tukey analysis.

In comparison with the assay using non-encapsulated cells, a more rapid uptake of gold was observed with cells within the alginate matrix because after the first hour of exposure to the metal, those cells captured $94 \%$ of the gold in the medium while the free cells captured only $41 \%$.

The analysis with SEM showed the presence of L. sphaericus CBAM5 within the alginate matrix (Figure 3a) and bacilli morphology was identified. The detection of backscattered electrons (Figure 3b) allowed the identification of areas with different compositions. Using an EDS analysis of those areas (Figure 3c), the presence of gold aggregates and possible nanoparticles inside the matrix and on the surface of the cells was determined.

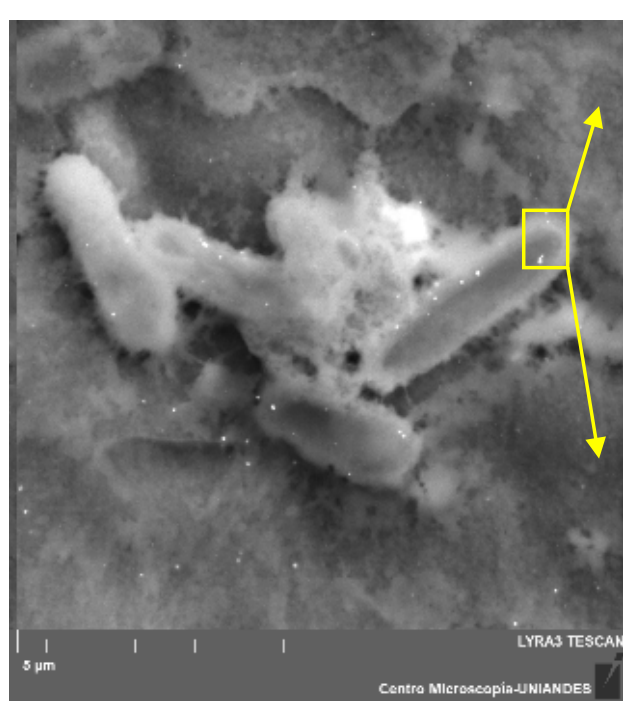

(a)

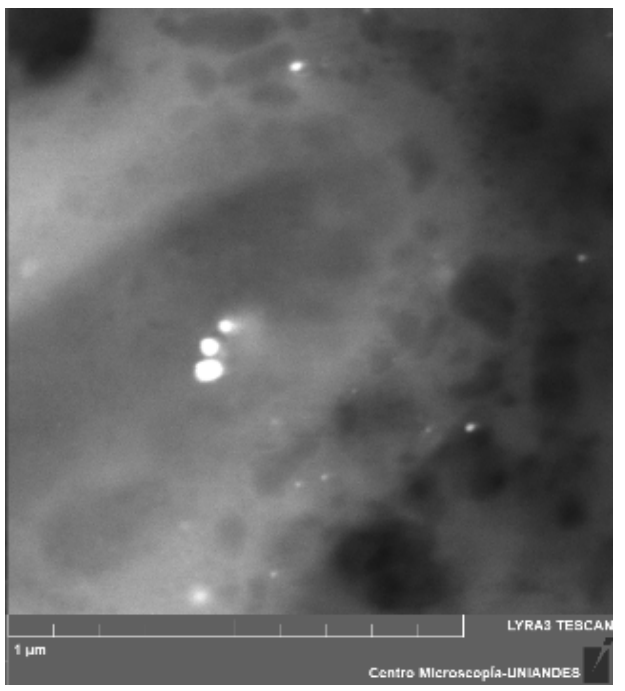

(b)

Figure 3. Cont. 


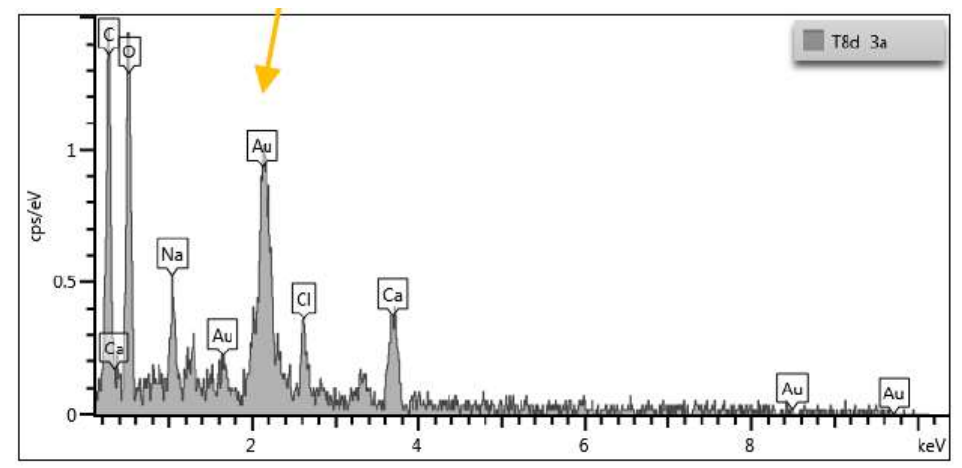

(c)

Figure 3. SEM micrographs of L. sphaericus CBAM5 cells (a) inside the alginate sphere seen with retro-dispersed electrons. (b) Close-up of image (a) seen with retro-dispersed electrons. (c) EDS analysis of image (b) showing the presence of $\mathrm{Au}$ in the matrix.

\subsection{Reusability Test and Release of Bacteria from Alginate Spheres}

In order to characterize the alginate matrix for the encapsulation of bacteria and its possible use for biotechnological applications, this study determined the reusability of the spheres and the bacteria released from them.

Firstly, the alginate spheres were used to test the release of encapsulated bacteria with an initial concentration of $2.13 \times 10^{6} \mathrm{CFU} / \mathrm{mL}$ by their immersion in a saline solution and incubation for $72 \mathrm{~h}$. Figure 4 shows that L. sphaericus CBAM5 was released from the alginate matrix immediately after exposure to saline solution and a bacterial concentration of $3.11 \times 10^{2} \mathrm{CFU} / \mathrm{mL}$ was determined in the medium.

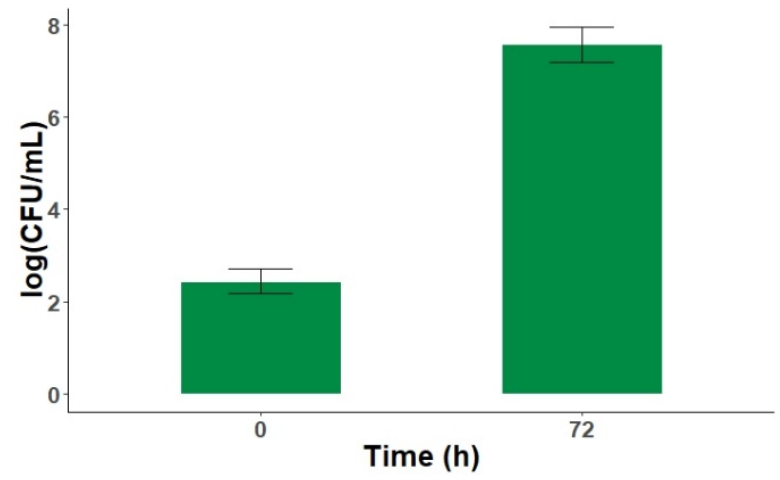

Figure 4. Release of bacteria from alginate beads. The bacterial concentration $(\log (\mathrm{CFU} / \mathrm{mL}))$ in the saline solution after $72 \mathrm{~h}$ of incubation is shown.

This release of bacteria was continuously observed after 24 and $48 \mathrm{~h}$ of incubation of the alginate spheres (data not shown). Finally, after $72 \mathrm{~h}$, a bacterial concentration of $2 \times 10^{6} \mathrm{CFU} / \mathrm{mL}$ was determined inside the spheres and one of $4.83 \times 10^{7} \mathrm{CFU} / \mathrm{mL}$ in the saline solution. It could be said that bacteria are being released into the medium and are able to continue their division phase, which explains the high titer in the saline solution. They can also divide inside the matrix, which explains the decrease of only $6 \%$ of the bacterial concentrations inside the alginate spheres after $72 \mathrm{~h}$ of incubation.

In order to identify the potential reusability of the encapsulated bacteria in alginate, the efficiency of gold capture was tested for three cycles. The results in Figure 5a show a decrease in the percentage of gold biosorption after the third cycle of reuse. Nevertheless, the efficiency continues to be higher $(60 \%)$ than that observed for the free L. sphaericus CBAM5 cells (51\%) in their first cycle. This reveals a clear advantage in the use of encapsulated cells for metal removal. 


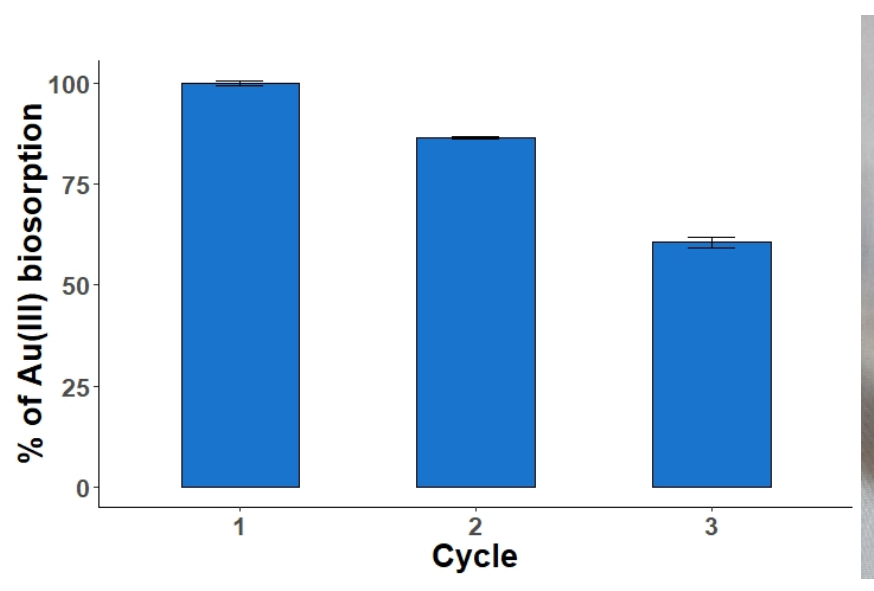

(a)

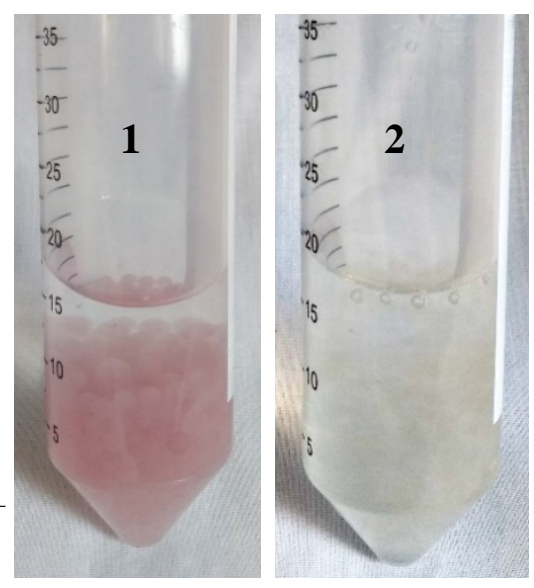

(b)

Figure 5. (a) Reusability of the encapsulated L. sphaericus CBAM5 cells for 3 cycles of $4 \mathrm{~h}$. (b) Bioassays with 1. Encapsulated CBAM5 and 2. Alginate spheres without bacteria, showing the difference of color in the matrix obtained after 3 cycles of reuse.

Moreover, a visual difference was identified between the control bioassay and the treatment with bacteria in alginate spheres, as shown in Figure $5 \mathrm{~b}$. The alginate matrix took on a red-purple color indicating a possible biosynthesis of gold nanoparticles, characterized by this color [22]. This result correlates with the SEM micrograph of the alginate spheres with bacteria taken after the first cycle. Figure $3 \mathrm{~b}$ shows a close-up of a bacterial cell with gold particles of nanometric size, ranging from 200 to $600 \mathrm{~nm}$.

\section{Discussion}

Sustainability is a current global challenge but the massive extraction of metals from the environment interferes with the possibility of reaching this goal [23]. Great efforts are being made to develop circular economies in an attempt to minimize waste by giving it value and by replacing mass production [24]. In this respect, the recovery and reuse of metals is an interesting alternative with which to approach sustainability. Biosorption has been described as a low-cost method for metal recovery and the use of microorganisms with bio-derived materials could serve as sustainable technology for industries [23] that operate with precious metals with high economic value, such as gold [25].

Alginate is a polysaccharide produced by algae and, given the presence of carboxylic groups in its structure, it has been studied as a metal-binding polymer [26,27]. It has also been used as an immobilization matrix given its simple preparation method [27]. In this study, L. sphaericus, a bacterium with a high metal-binding capacity $[12,14,15]$, was chosen for encapsulation in an alginate matrix, improving its efficiency to capture gold to $100 \%$ in a period of just $3 \mathrm{~h}$.

Several strains of L. sphaericus were chosen to determine their potential to capture gold from aqueous media. As shown in Figure 1, L. sphaericus CBAM5 showed the highest efficiency and it might present different mechanisms to achieve this. For instance, L. sphaericus CBAM5 is known for having an S-layer protein present in the external cell envelope, capable of self-assembly, and with a P4 symmetry $[28,29]$. This protein is known to have a high affinity to metals and its functional groups are able to bind $\mathrm{Au}(\mathrm{III})$ in a stable and efficient way [5]. The bacteria could present other resistance mechanisms like gold absorption and accumulation inside the cell by sequestration. There was no evidence of efflux pumps being activated during the bioassays because no oscillations of the gold concentration in the supernatant were observed (Figure 1).

Moreover, as shown in Figure 2, the encapsulated L. sphaericus CBAM5 was able to remove nearly $100 \%$ of the gold from the aqueous media in three hours, making alginate a suitable polymer for the optimization of metals sorption processes in biotechnological applications. 
The relevance of alginate as an immobilization matrix lies in its biodegradable potential and its non-toxic nature [18]. It provides a controlled environment for the bacteria by protecting them from stress conditions such as UV radiation, contaminants, and desiccation, among others. Due to its tortuosity, the alginate matrix is also able to control the diffusion of the aqueous media towards the encapsulated cells, increasing the contaminant retention time $[17,19]$ and improving L. sphaericus CBAM5's efficiency in capturing metals such as gold.

The tortuosity of the matrix also determines the release of bacteria into the medium. In this study, it was determined that $L$. sphaericus CBAM5 can be released from the alginate spheres after $72 \mathrm{~h}$ of incubation because a high titer of bacteria was found in the saline solution (Figure 4). Nevertheless, the bacterial concentration remained high inside the alginate matrix, with a decrease of only $6 \%$. It is proposed that cell division can be achieved in a saline solution and inside the alginate matrix due to energy reserves available for the microorganisms acting as autotrophs in nutrient-limiting conditions. These promising results showed that the alginate beads could be reused for enhanced gold biosorption for at least $72 \mathrm{~h}$ because high titers of bacteria remain in the spheres, despite the fact that they could be released into the environment. Future studies with a longer period of time should be conceived.

To study the reusability of the encapsulated cells (Figure 5), the alginate spheres with L. sphaericus CBAM5 were reused for three cycles of exposure to a gold solution. An efficiency of $60 \%$ was retained after the cycles. This decrease in the gold biosorption might indicate a level of saturation of the proteins capable of metal adsorption on the external layer of the bacteria, specifically the S-layer protein, which is abundant in L. sphaericus [5].

Finally, a model explaining the possible interactions of gold with the bacteria and the matrix is shown in Figure 6. Gold in solution is absorbed by the alginate beads due to their porous structure that controls the diffusion of the aqueous media. The metal can also be adsorbed by the matrix which is made up of mannuronic and glucuronic acid, which are able to bind with $\mathrm{Au}(\mathrm{III})$ complexes [27]. L. sphaericus CBAM5 inside the matrix can also adsorb gold through its S-layer protein assembled in the cell wall. An accumulation of gold inside the cells could also be occurring, and it is proposed that metabolic active bacteria are responsible for the synthesis of gold nanoparticles. Although the reduction pathway was not studied here, it is suggested that a rapid reduction of $\mathrm{Au}(\mathrm{III})$ to $\mathrm{Au}(\mathrm{I})$ occurs in the cell wall and is followed by a slow reduction to $\mathrm{Au}(0)$ [30]. This reduction pathway could compromise the S-layer [31] and a mer-like cluster, the latter of which confers microbial resistance to mercury by reducing the toxic metal to $\mathrm{Hg}(0)$ with the reductase enzyme, MerA [32]. This enzyme could also work on gold species due to the similarities between the metals [30].

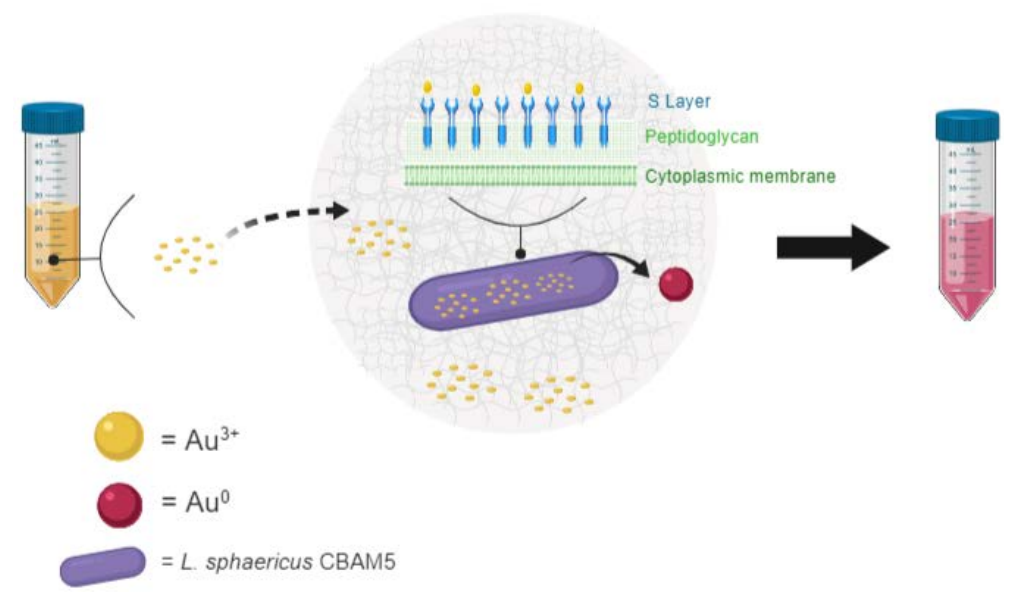

Figure 6. Scheme indicating the main processes that may occur in the encapsulated cells after exposure to $\mathrm{Au}(\mathrm{III})$ : adsorption through the S-layer, absorption and accumulation inside the bacterial cell and inside the alginate matrix. A possible gold nanoparticles biosynthesis was observed. 
For future studies, a protocol for the extraction and characterization of the gold nanoparticles should be standardized. Also, the gold reduction pathway should be identified.

Author Contributions: Conceptualization, C.P.-V. and J.D.; formal analysis, C.P.-V.; funding acquisition, J.D.; investigation, C.P.-V. and J.D.; methodology, C.P.-V., R.E.R. and J.D.; project administration, J.D.; resources, R.E.R. and J.D.; supervision, J.D.; validation, C.P.-V.; visualization, C.P.-V.; writing-original draft, C.P.-V.; writing-review and editing, C.P.-V., R.E.R. and J.D.

Funding: This research was funded by the Research Fund at the School of Science at Universidad de los Andes call 2019-1 for the Financing of Projects of Investigation and Participation in Academic Events Category Master Students, project code INV-2018-34-1265 and the Microbiological Research Center (CIMIC). APC was funded by School of Science at Universidad de los Andes and the Microbiological Research Center (CIMIC).

Acknowledgments: We would like to acknowledge Monica Beatriz López Santos for all her contributions and support at EDS-SEM analysis at Microscopy Center in Universidad de Los Andes. We would also like to thank Maria Camila Bustos for starting the work on this area of research in the Microbiological Research Center (CIMIC) and for all her advices in the beginning of this study. We also thank Tiziana Laudato for the English grammar corrections provided.

Conflicts of Interest: The authors declare no conflict of interest. The funders had no role in the design of the study; in the collection, analyses, or interpretation of data; in the writing of the manuscript, or in the decision to publish the results.

\section{References}

1. Suhr, M.; Raff, J.; Pollmann, K. Au-Interaction of Slp1 Polymers and Monolayer from Lysinibacillus sphaericus JG-B53-QCM-D, ICP-MS and AFM as Tools for Biomolecule-metal Studies. J. Vis. Exp. 2016, 107, e53572. [CrossRef] [PubMed]

2. Johnson, D.B. Biomining-biotechnologies for extracting and recovering metals from ores and waste materials. Curr. Opin. Biotechnol. 2014, 30, 24-31. [CrossRef] [PubMed]

3. Javanbakht, V.; Alavi, S.A.; Zilouei, H. Mechanisms of heavy metal removal using microorganisms as biosorbent. Water Sci. Technol. 2014, 69, 1775-1787. [CrossRef] [PubMed]

4. Gupta, A.; Joia, J. Microbes as Potential Tool for Remediation of Heavy Metals: A Review. J. Microb. Biochem. Technol. 2016, 8, 364-372. [CrossRef]

5. Suhr, M.; Unger, N.; Viacava, K.E.; Günther, T.J.; Raff, J.; Pollmann, K. Investigation of metal sorption behavior of Slp1 from Lysinibacillus sphaericus JG-B53: A combined study using QCM-D, ICP-MS and AFM. BioMetals 2014, 27, 1337-1349. [CrossRef] [PubMed]

6. Roane, T.M.; Rensing, C.; Pepper, I.L.; Maier, R.M. Microorganisms and Metal Pollutants, 2nd ed.; Elsevier: Amsterdam, The Netherlands, 2012.

7. Volesky, B. Biosorption and me. Water Res. 2007, 41, 4017-4029. [CrossRef]

8. Leung, W.C.; Chua, H.; Lo, W. Biosorption of Heavy Metals by Bacteria Isolated from Activated Sludge. In Twenty-Second Symposium on Biotechnology for Fuels and Chemicals; Humana Press: Totowa, NJ, USA, 2001; pp. 171-184.

9. Merroun, M.L.; Raff, J.; Rossberg, A.; Hennig, C.; Reich, T.; Selenska-Pobell, S. Complexation of uranium by cells and S-layer sheets of Bacillus sphaericus JG-A12. Appl. Environ. Microbiol. 2005, 71, 5532-5543. [CrossRef]

10. Fahmy, K.; Merroun, M.; Pollmann, K.; Raff, J.; Savchuk, O.; Hennig, C.; Selenska-Pobell, S. Secondary Structure and $\mathrm{Pd}(\mathrm{II})$ Coordination in S-Layer Proteins from Bacillus sphaericus Studied by Infrared and X-Ray Absorption Spectroscopy. Biophys. J. 2006, 91, 996-1007. [CrossRef]

11. Peña-Montenegro, T.; Lozano, L.; Dussán, J. Genome sequence and description of the mosquitocidal and heavy metal tolerant strain Lysinibacillus sphaericus CBAM5. Stand. Genomic Sci. 2015, 10, 2-10. [CrossRef]

12. Varg, J.E.; Dussán, J. Encapsulation and immobilization of the S-layer protein of Lysinibacillus sphaericus in an alginate matrix for chromium adsorption. Int. Biodeterior. Biodegrad. 2017, 116, 141-146. [CrossRef]

13. Tsuruta, T. Biosorption and recycling of gold using various microorganisms. J. Gen. Appl. Microbiol. 2004, 50, 221-228. [CrossRef] [PubMed]

14. Lozano, L.C.; Dussán, J. Metal tolerance and larvicidal activity of Lysinibacillus sphaericus. World J. Microbiol. Biotechnol. 2013, 29, 1383-1389. [CrossRef]

15. Bustos, M.C.; Ibarra, H.; Dussán, J. The golden activity of Lysinibacillus sphaericus: New insights on gold accumulation and possible nanoparticles biosynthesis. Materials 2018, 11, 1587. [CrossRef] [PubMed] 
16. Keweloh, H.; Heipieper, H.J.; Rehm, H.J. Protection of bacteria against toxicity of phenol by immobilization in calcium alginate. Appl Microbiol Biotechnol 1989, 31, 383-389. [CrossRef]

17. Covarrubias, S.A.; De-Bashan, L.E.; Moreno, M.; Bashan, Y. Alginate beads provide a beneficial physical barrier against native microorganisms in wastewater treated with immobilized bacteria and microalgae. Appl. Microbiol. Biotechnol. 2012, 93, 2669-2680. [CrossRef] [PubMed]

18. Bashan, Y.; Hernandez, J.P.; Leyva, L.A.; Bacilio, M. Alginate microbeads as inoculant carriers for plant growth-promoting bacteria. Biol. Fertil. Soils 2002, 35, 359-368. [CrossRef]

19. Quan, L.M.; Khanh, D.P.; Hira, D.; Fujii, T.; Furukawa, K. Reject water treatment by improvement of whole cell anammox entrapment using polyvinyl alcohol/alginate gel. Biodegradation 2011, 22, 1155-1167. [CrossRef]

20. Peña-Montenegro, T.D.; Dussán, J. Genome sequence and description of the heavy metal tolerant bacterium Lysinibacillus sphaericus strain OT4b.31. Stand. Genomic Sci. 2013, 9, 42-56. [CrossRef]

21. Naghili, H.; Tajik, H.; Mardani, K.; Razavi Rouhani, S.M.; Ehsani, A.; Zare, P. Validation of drop plate technique for bacterial enumeration by parametric and nonparametric tests. Vet. Res. Forum 2013, 4, 179-183.

22. Piella, J.; Bastús, N.G.; Puntes, V. Size-Controlled Synthesis of Sub-10-nanometer Citrate-Stabilized Gold Nanoparticles and Related Optical Properties. Chem. Mater. 2016, 28, 1066-1075. [CrossRef]

23. Dodson, J.R.; Parker, H.L.; Muñoz García, A.; Hicken, A.; Asemave, K.; Farmer, T.J.; He, H.; Clark, J.H.; Hunt, A.J. Bio-derived materials as a green route for precious \& critical metal recovery and re-use. Green Chem. 2015, 17, 1951-1965.

24. Geissdoerfer, M.; Savaget, P.; Bocken, N.M.P.; Hultink, E.J. The Circular Economy-A new sustainability paradigm? J. Clean. Prod. 2017, 143, 757-768. [CrossRef]

25. Cui, J.; Zhang, L. Metallurgical recovery of metals from electronic waste: A review. J. Hazard. Mater. 2008, 158, 228-256. [CrossRef] [PubMed]

26. Park, Y.; Hong, Y.N.; Weyers, A.; Kim, Y.S.; Linhardt, R.J. Polysaccharides and phytochemicals: A natural reservoir for the green synthesis of gold and silver nanoparticles. IET Nanobiotechnol. 2011, 5, 69-78. [CrossRef] [PubMed]

27. Torres, E.; Mata, Y.N.; Blázquez, M.L.; Muñoz, J.A.; González, F.; Ballester, A. Gold and Silver Uptake and Nanoprecipitation on Calcium Alginate Beads. Langmuir 2005, 21, 7951-7958. [CrossRef] [PubMed]

28. Liu, J.; Falke, S.; Drobot, B.; Oberthuer, D.; Kikhney, A.; Guenther, T.; Fahmy, K.; Svergun, D.; Betzel, C.; Raff, J. Analysis of self-assembly of S-layer protein slp-B53 from Lysinibacillus sphaericus. Eur. Biophys. J. 2017, 46, 77-89. [CrossRef] [PubMed]

29. Teixeira, L.M.; Strickland, A.; Mark, S.S.; Bergkvist, M.; Sierra-Sastre, Y.; Batt, C.A. Entropically driven self-assembly of Lysinibacillus sphaericus S-layer proteins analyzed under various environmental conditions. Macromol. Biosci. 2010, 10, 147-155. [CrossRef]

30. Reith, F.; Etschmann, B.; Grosse, C.; Moors, H.; Benotmane, M.A.; Monsieurs, P.; Grass, G.; Doonan, C.; Vogt, S.; Lai, B.; et al. Mechanisms of gold biomineralization in the bacterium Cupriavidus metallidurans. Proc. Natl. Acad. Sci. 2009, 106, 17757-17762. [CrossRef]

31. Jankowski, U.; Merroun, M.L.; Selenska-Pobell, S.; Fahmy, K. S-Layer protein from Lysinibacillus sphaericus JG-A12 as matrix for $\mathrm{Au}(\mathrm{III})$ sorption and Au-nanoparticle formation. Spectroscopy 2010, 24, 177-181. [CrossRef]

32. Bafana, A.; Chakrabarti, T.; Krishnamurthi, K. Mercuric reductase activity of multiple heavy metal-resistant Lysinibacillus sphaericus G1. J. Basic Microbiol. 2015, 55, 285-292. [CrossRef]

(C) 2019 by the authors. Licensee MDPI, Basel, Switzerland. This article is an open access article distributed under the terms and conditions of the Creative Commons Attribution (CC BY) license (http://creativecommons.org/licenses/by/4.0/). 